\title{
BROADENING THE NOTION OF RETRANSLATION
}

\author{
Vitor Alevato do Amaral ${ }^{1}$ \\ -Universidade Federal Fluminense, Niterói, Brasil
}

\begin{abstract}
The purpose of the present article is to problematize the current definitions of retranslation by discussing one of their constituent aspects: the limitation to the same target language into which a given source text has already been translated. What justifies the present paper is the lack of theoretical discussion about definitions of retranslation in academic works. Most studies take them for granted and obviate the need to escape the enticing stability that marks them. Our view is that retranslation also takes place outside the limits established by a single target language, and, because of this, it must be treated as a multilingual concept. We will illustrate our view with theoretical positions, mainly by Antoine Berman, and examples from retranslations of two literary works by James Joyce (1882-1941), Dubliners (1914) and Ulysses (1922), in French, German, Italian, Portuguese, and Spanish.
\end{abstract}

Keywords: Retranslation; Translation; James Joyce; Dubliners; Ulysses

\section{AMPLIANDO A NOÇÃO DE RETRADUÇÃO}

Resumo: O propósito do presente artigo é problematizar as definições correntes de retradução, através da discussão de um de seus aspectos constituintes: a limitação à mesma língua-meta para a qual determinado texto-fonte já foi traduzido. O que justifica o presente artigo é a falta de discussão teórica acerca das definições de retradução em trabalhos acadêmicos. A maioria dos estudos as toma como certas e evita a necessidade de se escapar à fascinante estabilidade que as marca. Nossa visão é a de que a retraducão também ocorre fora dos limites estabelecidos por uma única língua-meta, e, devido a isso, deve ser tratada como um conceito multilíngue. Ilustraremos nossa visão com posições teóricas, especialmente as de Antoine Berman, e com exemplos de retraduções de 
duas obras literárias de James Joyce (1882-1941): Dubliners [Dublinenses] (1914) e Ulysses (1922) para o francês, o alemão, o italiano, o português e o espanhol.

Palavras-chave: Retradução; Tradução; James Joyce; Dubliners; Ulysses

\section{Introduction to the problem}

Definitions of translation are as vexed as abundant. They vary from direct formulations, like J. C. Catford's "a process of substituting a text in one language for a text in another" (1), to essayistic ones, like Antonio Prete's "to transmute a language into another language. A text into another text. A voice into another voice. There is, in this alchemy, something similar to the love experience, or at least to its tension" (11; our trans.). On the other hand, definitions of retranslation are much less controversial and varied. They tend to revolve around one formulation - a new translation of a source text previously translated into the same target language - that is accepted without much or any debate and represents the current notion of retranslation.

The purpose of the present article is to problematize the current notion of retranslation by discussing one of the constituent aspects of its definitions: the limitation to one target language. As examples will prove, this aspect crystalizes in the part of definitions that restrict retranslation to new renderings of a source text into the same target language. The narrowness of the scope of research in retranslation, and the treatment of retranslation more as process and product than concept are two of the negative results of keeping such a potentially polyglot phenomenon closed in bilingualism.

Discussing the existing definitions of retranslation is imperative to the formulation of new definitions informed by a polyglot and intertextual notion of retranslation, a notion that is in accordance with the actual practice of translation and translation research. Our contention is that the presence of a common target language is not necessary for the characterization of a translation as a retranslation. 
It is up to the readers' discretion to choose to read any other translation of a source text, even if it is the first one in a given target language, as a retranslation. This approach broadens the notion of retranslation, with positive consequences for research and for the reading of translations in general. For this paper, we have selected some relevant theoretical positions, mainly by Antoine Berman, and retranslation cases of two literary works by James Joyce (18821941), Dubliners (1914) and Ulysses (1922), in French, German, Italian, Portuguese and Spanish.

\section{Theoretical support for a broader notion of retranslation}

Some authors have claimed that the concept of retranslation needs to be studied more deeply, as do Şebnem Susam-Sarajeva: "Currently, there is no detailed or systematic study on retranslations per se. Although the practice itself is common, theoretical discussions on the subject are rather rare" (2); Annie Brisset: "One may be surprised that such a frequent phenomenon as retranslation has triggered so little critical reflection after all" (41; our trans.); Juan Jesús Zaro Vera: “The concept of 'retranslation' ... has not been explored in depth ..." (21; our trans.); Enrico Monti: "The vast dissemination of the practice of retranslation within the European literary space has not been sufficiently explored in its multiple challenges" (10; our trans.); and Sharon Deane-Cox: "a cogent empirical and conceptual understanding of retranslation remains elusive" (1). These quotes date from 2003, 2004, 2007, 2011, and 2014. Even though it is undeniable that the scene changed within those eleven years, and continues to change, the stability of the definitions of retranslation has barely been discussed.

Theoretical papers on the subject hardly ever attempt to discuss the existing definitions. On the contrary, most of them either choose a working definition or take retranslation for granted. The differentiation between retranslation as back-translation, indirect translation, and what we can call retranslation proper, which 
appears in some works, is an example of how authors either helped to build or continue to follow the current notion of retranslation (Chevrel 11; Deane-Cox 194; Gambier, "La retraduction, retour et détour" 413, "La retraduction: ambiguïtés et défis" 52-53). To understand retranslation as a concept, one has to ask what it is, both as process and product. This is different from only marking the above-mentioned difference or asking, as it has commonly been asked in scholarly papers, what the motives for retranslating are. It is our view that in general the latter question has outweighed the former, consequently reinforcing the role of political, and commercial motivations - which normally thrive in a specific cultural context -, and helping to maintain the same-target-language factor practically unchallenged.

Many papers and books state what the working definition of retranslation is for them. It is easy to find examples: "a new translation, in the same language, of a text already entirely or partially translated" (Gambier, "La retraduction, retour et détour" 413; our trans.); "translation of the same source text, in the same language, carried out after another translation" (Gambier, "La retraduction: ambiguïtés et défis" 53; our trans.); "subsequent translations of a text, or part of a text, carried out after the initial translation which introduced this text to the 'same' target language" (Susam-Sarajeva 1); "the act of translating a work that has previously been translated into the same language ..." (Gürçağlar 233); "the repeated translation of a given work into a given language" (Deane-Cox 194); "a second or later translation of a single source text into the same target language" (Koskinen and Paloposki 294); and "new translation of a text already translated in the same target language ..." (Constantinescu 29; our trans.) (All emphases added).

Yves Chevrel explains that "[n]owadays the French term [retraduction] most often refers to a new translation, in the same target language, of a work already translated into that language" (11; the latter is our emphasis; our trans.). By the same token, Cecilia Alvstad and Alexandra Assis Rosa affirm that 
As has often been stressed, the multiple retranslations of a source text into the same target language constitute a privileged corpus to help uncover both broad contextual motivations ... and more specific factors related to the communicative situation ... (19; our emphasis).

In "En torno al concepto de retraducción" (On the Concept of Retranslation), Vera finds the "full virtuality and greatest efficacy" of retranslation in the texts translated "into the same language more than once" (31; our trans.). Consistently, the case chosen to illustrate the importance of recognizing "the merit of previous translations" concerns only Spanish as a target language (32; our trans.). Vera refers to a newspaper article in which Juan José Saer harshly criticizes José María Valverde, the second translator of Ulysses into Spanish (1976), for flouting the first translation (1945), by José Salas Subirat, and recognizes, in contrast, the respectful attitude of the authors of the third translation (1999): "No serious translator of Ulysses can ignore the existence of the first and second translations (and such is the honest principle adopted by the authors of the third one, Francisco García Tortosa and María Luisa Venegas Lagüéns) ...”, writes Saer (our trans.).

Most of the examples above come from articles or chapters that discuss retranslation from a theoretical perspective. Yet they expose, grosso modo, only one definition, in which the circumscription of retranslation to a practice occurring inside one target language is evident. We intend to demonstrate that the theory of retranslation has much to gain by abandoning the parti pris according to which target texts can only be characterized as retranslations as regards antecedent target texts in the same language. Enlarging the notion of retranslation will open new possibilities for research in the light of the retranslation theoretical framework that has been constructed at least since Berman's "La retraduction comme espace de la traduction" (1990).

Prior to the days when retranslation became a recurrent subject in Translation Studies, Berman had already been very 
clear about allowing retranslations to breathe outside the domain of a single language: "it is in retranslation, or rather, in retranslations, successive or simultaneous, that translation takes place. Not only in the space of the receiving language/ culture, but in other languages/cultures" (Pour une critique des traductions 84; our trans.). Berman's view allows foreignness to enter the domain of retranslation, avoiding ethnocentricity. But what could have shaped a broader notion of retranslation from the beginning has instead been smothered in the quasitotality of the approaches on the subject.

To make sure his perspective is understood, Berman goes into the minutiae of his proposal: "I mean, from this perspective, that the horizon of a French translation is tripartite: the previous translations in French; the other contemporary French translations; the foreign translations [traductions étrangères]." (84; our trans.). Reinforcing the third part of the retranslation horizon, Berman asserts that "in fact, one can consider every translation coming after another, even the foreign ones, ipso facto as a retranslation ..." (85; our trans.). In doing so, he treats retranslation as potentially multilingual.

It is an undeniable fact that many practitioners are familiar with one or more languages other than the ones they are translating from and into; languages that they usually bring to the scope of the translation process. Clearly, we should note, those are more often major languages, such as the ones used in this paper - French, German, Italian, Portuguese, and Spanish -, but minor languages are not excluded. "It is not rare that a translator 'consults' the foreign translations to translate a given work, even for the first time in their language", writes Berman (84; our trans.). But it is not necessary that translators scan previous translations in search of solutions or ways to establish the difference between the new and the previous translations, for, as Berman asserts, "it is enough that [the translators] know - even when they only hear about it [par ouï-dire] - that the source text has already been translated somewhere for the nature of their work to change" (84; our trans.). He exemplifies his assertion with cases from his own experience 
as a translator. For his translation of Roa Bastos's Yo el Supremo (Moi, le Suprême) he consulted the German translation, whereas for Roberto Arlt's Los siete locos (Les sept fous), he knew of the existence of Italian and German translations (84-85), which were enough to give him the consciousness of coming after.

In the light of the above remarks by Berman, we have solid ground to understand that when, in "La retraduction...", he states that "every translation made after the first translation of a work is therefore a retranslation" (1), he is aiming further away from a single target language. Besides, it is important to remember that Berman's desire to broaden the concept of retranslation - he uses the verb "élargir" (4) - is already present in the same essay when he proposes that "it is enough that one text by a given author has already been translated for the translation of other texts by the same author to enter the space of retranslation" (3).

It is indeed widely agreed that the prefix $r e$ - in retranslation does not denote the mere repetition or correction of a previous translation, although emendations can be done. When Tiphaine Samoyault states that "a retranslation is not only the translation of a text already translated, but a way of thinking about translation" (233; our trans.), and Berman calls attention to "re-translating" as "to translate in the manner of re-translation, which means in the most critical and most accomplished manner of translation" (L'âge de la traduction 20; our trans.), both authors emphasize its critical dimension, whose depth and range increase as it ceases to comply with the current praxis, which shortens research possibilities by preventing retranslation from fulfilling its multilingual vocation.

We endorse Alvstad and Rosa's assertion that "addressing retranslation as an object of study in its own right involves the task of conceptualization" (8). But, in our view, this conceptualization must be accompanied by the broadening of the notion of retranslation beyond the negotiation between two languages or cultures. One of the factors that obstructs such conceptualization is the current practice of studying retranslation cases as by norm culturally, geographically, and linguistically limited. 
The widely accepted notion of retranslation seems to be regulated by the perception of translation as a bridge between cultures on the one hand, and translators as cultural negotiators between a source and a receiving culture on the other hand. This perspective is fostered by the cultural imperative that informs most of the theory of retranslation. The focus on translations, particularly literary translations, as bridges between cultures, obscures the fact that the retranslation issues are as much cultural as aesthetic, and that resorting to other languages, instead of interposing a hindrance between the source and target cultures, actually causes an increase of the intertextual possibilities and can enhance the quality of translations linguistically, culturally, and aesthetically altogether.

By studying retranslations we get closer to the concept of retranslation, but the study of individual cases must have the major translation questions in perspective. A theory of retranslation must attract the complex (aesthetic, cultural, historical, linguistic, philosophical etc.) translation issues, which surpass the limits of two languages. Any accommodating practice that prevents the main problems within Translation Studies from reaching the theory of retranslation will both impoverish retranslation as thought, and narrow research possibilities. The difference between translation and retranslation is a matter of approach, therefore defining it as "a new translation" should not be an excuse to take translation for granted and keep translation problems apart. In such a detrimental separation, the most complex questions are less likely to be examined from the perspective of retranslation. Were this not an issue, Chevrel would not need to remind us that "retranslation remains a translation, and consequently conveys all problems related to the act of translating" (12; our trans.).

Retranslation is potentially polyglot and intertextual. It goes beyond the bilingual relation between one source language and one target language. The role of the readers is crucial to expand such relation, for they are entitled to bring to dialogue all the translations in as many languages as they can, and this contributes to a potentially unlimited and unpredictable new 
textuality. Alvstad and Rosa claim in their paper on voices in retranslation that "the web of intertextual voices becomes even more complex in retranslations than in first (or only) translations, as the intertextual influence from earlier translations of the same text (and their intertexts) also enters the game" (6). Nevertheless, as we have pointed out, the authors confirm the current notion of retranslation, so the intertextuality created by different voices remains inside a single target language, whereas our proposal is that it can expand to any language into which a given source text has been translated. The emphasis on the propensity of retranslation for intertextuality is central in our view, but the reach of this intertextuality should by no means be previously limited. Many research possibilities have been left out of the domain of retranslation exactly because of the too strict notion of retranslation that has been imposed on researchers.

\section{A case for thought: retranslations of Joyce}

An inspiring view on intertextuality is introduced by Patrick O'Neill in Polyglot Joyce. The author proposes a comprehensive approach covering the "transtextual" relation between the original and its translations in any language, thus capable of engendering a "polyglot macrotext" that would be read transtextually, i.e. through "a particular form of intertextual reading across languages" (10). Although the author does not use the term "retranslation", the similarity between his proposal and the concept of retranslation, as we have presented it in this paper, is remarkable. By exploring "the concept of multilingual and translingual textuality, looking for meaningful ways in which we can think of (and work with) all the many translations of a single major author's works as constituting, together with their originals, a single polyglot macrotext" (3), O'Neill stresses that intertextuality benefits from polyglottism. The rapport between retranslation and transtextual reading, which is still to be thoroughly studied, gives the readers a central role in 
building the textuality formed by originals and their retranslations, and generates new research possibilities.

In his book, O'Neill focuses on translations of four works into a small group of languages, but he highlights that his subject is "the worldwide translations of Joyce's literary works in all languages" (3). In the same way, retranslation can embrace, at least virtually, all translations of a single work in any language. In doing so, it will pave the way to innumerable research cases in the theoretical frame of retranslation. For example, a study of the retranslations of Joyce, which nowadays would be limited to the translations in French, in German, in Portuguese etc., could be determined by other criteria, and titles like "Retranslations of Dubliners in Western Europe" or "Retranslations of Ulysses in Romance Languages" would finally be seen.

Many examples of papers dealing with translations of a source text into different languages can be found. To keep our focus on Joyce, we will start by Christine O'Neill's “Entitled to Translate”, in which she discusses translations of the title of Joyce's book of short stories, Dubliners, into German, French, Italian, and Spanish. Title translation is in general a rich source of cases to be studied in retranslation, and her article raises interesting questions, such as why, in French, the title Gens de Dublin has been preferred to Dublinois, "even though the latter is a correct lexical formation" (65). The question has been investigated by us in the light of retranslation. The chronology of the titles in French is the following: in 1926, the book was published as Gens de Dublin (Fernandez et al.); in 1974, as Dublinois (Aubert); and, in 1994, again as Gens de Dublin (Tadié). Asked why he chose to reuse the first title, Benoît Tadié answered, among other things, that because the previous translation had appeared not so long before his own, the "choice was also a way of differentiating one work from the other and offering the readers the two possibilities" (Amaral 55).

There is more to this case in point. In Italian, out of the ten translations listed by O'Neill, only one translation appears as Dublinesi, while the others are Gente di Dublino, closer to the 
French inaugural Gens de Dublin. The same phenomenon occurs in Spanish; among the five translations consulted by O'Neill, four are Dublineses $(1961,1972,1993,1994)$, but the oldest one is Gente de Dublín (1942). Further to O'Neill's list, our research about Joyce translations found that Dubliners was translated into Portuguese (Portugal) three times; as Gente de Dublim (1963), Gente de Dublin (1994) and, finally, Dublinenses (2012). In the Brazilian variety of the Portuguese language, there are four published translations of the book (1964, 1993, two in 2012), all under the title Dublinenses, but it is important to note that before the first complete translation appeared in 1964, the book used to be referred to as Gente de Dublin. Given the linguistic facts above, it is possible to sustain the thesis according to which the French translation, being the first in a Romance language, plays a role in the history of the translations of Dubliners into Italian, Portuguese, and Spanish. According to Helena Buffery and Carmen MillánVarela, the influence of the French translation is also found in Catalan: "Early Catalan mentions of Ulysses as a classic of world literature refer to it as Ulisse (without the final 's' normally used in reproducing the proper name in Catalan), following French versions of the text" (402). However, if the notion of retranslation remains limited to new translations of a work into the same target language, the investigation of the retranslations of Joyce's title will stop at a linguistic wall, and the consequence will be that the possible impact of the French translation on the retranslations of Dubliners into other languages will be ignored by any study about Joyce retranslations.

A classic in Joyce Studies is Fritz Senn's "Seven against Ulysses" (1967), in which the Swiss author compares selected passages of translations of Joyce's novel into seven different languages: French, German, Spanish, Swedish, Danish, Italian, and Serbo-Croatian. One of the cases examined by Senn is the "Throwaway motif" (179). In the "Lotus Eaters" episode of Ulysses, Leopold Bloom unintentionally gives a tip to Bantam Lyons by telling him, "I was just going to throw it [the newspaper] 
away" (82). Coincidentally, Throwaway is the name of one of the horses that would participate in a race on that same day, as we learn from the "Cyclops" episode, in which Throwaway is said to have won (312). So, Bloom's idle "throw it away" and the name "Throwaway" are immediately associated by Bloom's interlocutor and taken as a suggestion for betting on the horse, an outsider that surprisingly wins at twenty to one. Senn discusses whether and how the translators managed to keep the link between "Throwaway" as the name of the horse, "throw away" as a verb, and "throwaway" as the handbill passed to Bloom's hand in "Lestrygonians" - "a somber Y. M. C. A. young man [...] placed a throwaway in a hand of Mr Bloom" (144). We will take the first French translation - by Auguste Morel, with the participation of Stuart Gilbert, Valery Larbaud and Joyce himself, published in 1929 - as a starting point to demonstrate how the multilingual comparative approach is an effective way to stress the connection between retranslations in different target languages.

In Morel's translation the horse is called Prospectus (366), but it is hard to believe that the readers of the novel can relate this name with the clue in Bloom's fortuitous comment, which in the translation becomes nothing else than "J'allais justement le jeter" (95), where the word prospectus is not found; it is found only in "un sombre jeune Y. M. C. A. ... mit un prospectus dans la main de M. Bloom" (169). Seventy-five years later, the second translation of Ulysses into French (2004) is made by a team of eight people under the coordination of Jacques Aubert. In contrast with Morel's, the Aubert translation pays special attention to the Throwaway motif, so much that one of the members of the team, Bernard Hœpffner, chooses exactly this case to explain how the team of eight would negotiate solutions during the collective translation (110). The result is that in the 2004 translation the name of the horse is Jetsam (532) to echo the previous "il fallait que je jette ça" (170; our emphasis). It is interesting to learn also how two Argentinian translations to which the 1929 French translation served as reference (Zabaloy 7; Petersen 300-301) deal with the 
same motif. Salas Subirat's translation (1945), the first in Spanish, is the only one to completely miss the throwaway motif, according to Senn (36), while Marcelo Zabaloy's does not reproduce the Joycean word-play but opts for adding an endnote explaining the misunderstanding between Lyons and Bloom $(95,323,739)$. The intertextuality established between the four translations reveals that both theory and practice of retranslation have only to gain by abandoning the current path and accepting that Morel's, Salas Subirat's, Aubert et al.'s, and Zabaloy's can be regarded as constitutive of a single retranslation case.

Although only briefly discussed in this paper, the two cases from Joyce - the retranslations of the name of the horse in Ulysses and that of the title, Dubliners - serve as examples of many more cases which could be included in a broader discussion. The comparative approach, applied by O'Neill and Senn, encourages a reciprocal illumination between the translations of Dubliners in different languages, accentuating the qualities of the original as well as the translators' creativity - or lack of it. It helps to comprehend the strategies used in order to translate Joyce's wordplay, whose ingenuity grows when regarded in the multilingual textuality constructed by scholars. The comparative approach connects different translations in a polyglot textuality, within which it is possible to read them as retranslations. We see the operation of a manner of reading that can help to raise the prefix re-from the shallowness of reiteration and infuses it with the force capable of turning retranslation from only process and product to concept. Nevertheless, in the current trend, such approach would not fit the academic scheme forged to retranslation because it breaks with the linguistic and cultural limits that have been naturalized and are now very much ingrained in the general mindset.

In the entry "Comparative Approaches to Translation" of the Handbook of Translation Studies, Cees Koster explains that "different kinds of comparisons may be envisaged", but "any comparative effort necessarily involves a corpus" (21). The author points out that, in respect to retranslations, different renderings of 
the same source text can form a corpus of translations in one or more target languages, for the sake of comparison (22). In passing, and contradicting the definition supplied in the entry "Retranslation" of the previous volume of the same Handbook, Koster expands the notion of retranslation to embrace translations in more than one target language. It is symptomatic that unorthodox views on the concept of retranslation originate in comparative studies. Berman and Koster, immersed in the polyglottism of the comparative approaches - the former practically, to compare translations of John Donne's "Going to Bed", and the latter theoretically, to summarize the comparative perspective in translation for a companion perceive the restriction to one target language as a limitation to thinking about (re)translation.

Nicolas Waquet elucidates the role of foreign translations (traductions étrangères) - he uses the same phrase as Berman in two above quotations - by recognizing that they:

shed, on the same work, a different syntactical and lexical light. They allow the retranslators to maintain some distance from the source text more easily, help them to abandon the original formulation of the thought. They encourage them also to take some liberties either to render certain nuances or shape certain sentences that the English language, for example, will express with its enviable innate possibilities. The malleability and facility of English to transpose the free precision of Greek are in fact of great help when the stricter demand of French tends to paralyze the process of rendition (280-281; our trans.).

In other words, whenever the character of the French language at first does not offer the resources for the translation of a word or phrase from Greek, retranslators can find in English the encouragement to test the plasticity of the target language. With this, Waquet is arguing that translations in target languages different from the ones in which the retranslators are writing are 
more than reservoirs of possible solutions that they can resort to in order to solve their own problems. This is only the tip of the issue. The solutions suggested by translations in different languages can trigger the creativity of the translators and ease their feeling of hesitation in welcoming a foreign turn into the target language. And the theory of retranslation can do more than acknowledge this fact. When one or more translations, in one or more target languages, become involved in the process of either writing other translations or reading translations - suppose, for criticism -, it must be open to encompass all existing translations, with the exception of the first one, as retranslations.

It is accepted without debate that the 2004 French translation of Ulysses by Aubert et al. is a retranslation as regards the 1929 translation by Morel into the same language, but why would it not be a retranslation also vis à vis, for example, the 1927 German translation by Georg Goyert? Joyce himself was a linchpin of the two earlier translations, inasmuch as he had a say in both. Joyce was upset when in 1926 the Swiss publishing house Rhein-Verlag wanted to "rush out ... with a translation" of Ulysses of which he had "verified 88 pages" only (Selected Letters 315). However, as O'Neill (52) explains, the 1930 edition of the German translation was reworked by Joyce "personally with Goyert". Concerning the first French translation, Joyce's part is well-known and has been publicized in all editions since 1929, often on the cover of the book. But even if the connection between these two early major translation tasks did not exist, or if one could naively imagine that none among the team under the coordination of Aubert had ever heard of the first German Ulysses, still the latest French Ulysse could be read as a retranslation in relation to Morel's and Goyert's renderings as well as to any other translation of Joyce's novel that readers were aware of.

In the same train of thought, knowing that Salas Subirat, and Zabaloy, consulted the 1929 French translation, the question is: how much of the French text is in these two Spanish-language translations of the novel? It calls upon the readers to penetrate the 
possible intertextualities between the three texts. But, if the samelanguage factor prevails, it will not be a retranslation question, that is, it will neither benefit from the knowledge constructed by the theory of retranslation nor contribute to the development of that same theory. Zabaloy's work is a retranslation of Ulysses because it comes after Salas Subirat's and Morel's translations. Prioritizing the French translation whenever four other English editions of Ulysses differed from each other (7), Zabaloy establishes a strong connection with the text in French. Although the language of the source text was English, the participation of the French text in Zabaloy's work must have been very relevant, considering the number of divergences between the editions of Ulysses in English (an analysis of the Argentinian translation against the English editions used and the first French is necessary to understand the role of Morel's translation in the process). When an expanded notion of retranslation is applied to the case under consideration, Zabaloy's translation can be regarded as a retranslation of Ulysses in respect to the existing French- and Spanish-language translations. More importantly, scholars are entitled to read the original - Ulysses (1922 or subsequent editions) - and its translations - Ulysse in French (1929, 2004), Ulysses in German (1927), and Ulises in Spanish $(1945,1976,1999,2015)$, to limit a much larger and potentially ever-growing list only to the translations mentioned in this paper - as a new Joycean (inter)textuality.

\section{Conclusion}

In conclusion, a retranslation is another translation of a text so considered, while retranslation is a stance and a way of reading and translating. Previous translations of a given text are not only a condition for the existence of retranslations, but also for them to exist in relation to other translations of the same text in various languages as well as for the translators to contribute to the formation of a virtually ever-expanding intertextuality made by the original and 
its translations in different languages. Discussing the definitions of retranslation is a means toward modifying the status quo that has for more than two decades informed books, entries, chapters, articles etc. Clearly, the concept of retranslation is still a long way from being satisfactorily studied. We hope this paper is a kick-off.

\section{References}

Alvstad, Cecilia, and Rosa, Alexandra Assis. "Voice in Retranslation. An Overview and Some Trends". Target, vol. 27, no.1, 2015, pp. 3-24.

Amaral, Vitor Alevato do. "Interview with a Dubliners Translator: Benoît Tadié". ABEI Journal. The Brazilian Journal of Irish Studies, no. 16, 2014, pp. 53-56.

Berman, Antoine. L'âge de la traduction. "La tâche du traducteur" de Walter Benjamin. Presses Universitaires de Vincennes, 2008.

2013.

. Pour une critique des traductions: John Donne. 1995. Éditions Gallimard,

. "La retraduction comme espace de la traduction". Palimpsestes, no. 4, 1990, pp. 1-7.

Brisset, Annie. "Retraduire ou le corps changeant da la connaissance sur l'historicité de la traduction”. Palimpsestes, no. 15, 2004, pp. 39-67.

Buffery, Helena, and Millán-Varela, Carmen. "Translations of Joyce in Spain: The Location of 'Ithaca'". The Modern Language Review, vol. 95, no. 2 (Apr., 2000), pp. 399-414.

Catford, J. C. A Linguistic Theory of Translation. 1965. Oxford University Press, 1974.

Cad. Trad., Florianópolis, v. 39, nº 1, p. 239-259, jan-abr, 2019. 
Chevrel, Yves. "Introduction: la retraduction - und kein Ende". La retraduction, edited by Robert Kahn, and Catriona Seth, Publications des Universités de Rouen et du Havre, 2010, pp. 11-20.

Constantinescu, Muguraş. Pour une lecture critique des traductions. Réflexions et pratiques. L'Harmattan, 2013.

Deane-Cox, Sharon. Retranslation. Translation, literature and reinterpretation. Bloomsbury, 2016.

Gambier, Yves. "La retraduction: ambiguités et défis". Autour de la retraduction. Perspectives littéraires européennes, edited by Enrico Monti, and Peter Schneyder, Orizons, 2011, pp. 49-66. $\overline{413-417}$

. "La retraduction, retour et détour". Meta, vol. 39, no. 3, 1994, pp.

Gürçağlar, Şehnaz Tahir. "Retranslation". Routledge Encyclopedia of Translation Studies, 2nd ed., edited by Mona Baker, and Gabriela Saldanha, Routledge, 2009, pp. 233-236.

Hœpffner, Bernard. "Les errances d'Ulysse, ou Ulysse Astray". Autour de la retraduction. Perspectives littéraires européennes, edited by Enrico Monti, and Peter Schneyder, Orizons, 2011, pp. 105-112.

Joyce, James. Dublinenses. Translated by Hamilton Trevisan. Civilização Brasileira, 1964.

. Dublinenses. Translated by José Roberto O'Shea. Siciliano, 1993.

. Dublinenses. Translated by José Roberto O’Shea. Hedra, 2012.

. Dublinenses. Translated by Silva Braga. L\&PM, 2012.

. Dublinenses. Translated by Margarida Periquito. Relógio D’Á'gua, 2012. 
.. Dubliners. 1914. Edited by Robert Scholes, Viking Press, 1968.

2008.

. Dublinois. Translated by Jacques Aubert. 1974. Éditions Gallimard,

. Gens de Dublin. 1926. Translated by Yva Fernandez,Hélène du Pasquier, and Jacques-Paul Reynaud. Plon, 1963.

. Gens de Dublin. Translated by Benoît Tadié. Flammarion, 1994.

. Gente de Dublim. Translated by Virgínia Motta. Livros do Brasil, 1963.

. Gente de Dublin. Translated by Isabel Veríssimo. Publicações EuropaAmérica, 1994.

. Ulises. Translated by José Salas Subirat. Santiago Rueda Editor, 1945.

. Ulises. 1976. Translated by José María Valverde. Lumen, 2014.

. Ulises. 1999. $7^{\text {th }}$ ed. Translated by Francisco García Tortosa, and María Luisa Venegas Lagüéns. Cátedra, 2009.

. Ulises. Translated by Marcelo Zabaloy. El Cuenco de Plata, 2015.

. Ulysse. 1929. Translated by Auguste Morel. James Joyce. CEuvres, vol.

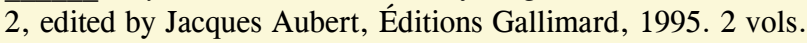

. Ulysse. 2004. Revised in 2013. Translated by Jacques Aubert, Pascal Bataillard, Michel Cusin, Sylvie Doizelet, Patrick Drevet, Stuart Gilbert, Bernard Hœpffner, Valery Larbaud, Auguste Morel, Tiphaine Samoyault, and MarieDanièle Vors, Éditions Gallimard, 2014.

. Ulysses. 1922. Edited by Jeri Johnson. Oxford University Press, 2008.

. Ulysses. 1927. Translated by Georg Goyert, Deutscher Taschenbuch

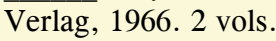


Press, 1975.

Selected Letters of James Joyce. Edited by Richard Ellmann. The Viking

Koskinen, Kaisa, and Paloposki, Outi. "Retranslation”. Handbook of Translation Studies, vol. 1, edited by Yves Gambier, and Luc van Doorslaer, John Benjamins, 2010, pp. 294-298. 4 vols.

Koster, Cees. "Comparative Approaches to Translation". Handbook of Translation Studies, vol. 2, edited by Yves Gambier, and Luc van Doorslaer, John Benjamins, 2011, pp. 21-25. 4 vols.

Monti, Enrico. Introduction. Autour de la retraduction. Perspectives littéraires européennes, edited by Enrico Monti, and Peter Schneyder, Orizons, 2011, pp. 10-25.

Noguera, Francisco Ruiz, and Vera, Juan Jesús Zaro, editors. Retraducir: una nueva mirada. La retraducción de textos literarios y audiovisuales. Miguel Gómez, 2007.

O’Neill, Christine. "Entitled to Translate". A New and Complex Sensation. Essays on Joyce's Dubliners, edited by Oona Frawley, The Lilliput Press, 2004, pp. 64-80.

O’Neill, Patrick. Polyglot Joyce. Fictions of Translation. University of Toronto Press, 2005.

Petersen, Lucas. El traductor del Ulises. Salas Subirat. La desconocida historia del argentino que tradujo la obra maestra de Joyce. Sudamericana, 2016.

Prete, Antonio. All'ombra dell'altra lingua. Per una poetica della traduzione. Bollati Boringhieri, 2011.

Saer, Juan José. "El destino en español del Ulises”. El País, 12 June 2004. elpais. com/diario/2004/06/12/babelia/1086997822_850215.html

Samoyault, Tiphaine. "Retraduire Joyce". La retraduction, edited by Robert Kahn, and Catriona Seth, Publications des Universités de Rouen et du Havre, 2010, pp. 231-240.

Cad. Trad., Florianópolis, v. 39, n 1, p. 239-259, jan-abr, 2019. 
Senn, Fritz. "Seven against Ulysses". James Joyce Quarterly. vol. 4, no. 3, 1967, pp. 170-193.

Susam-Sarajeva, Şebnem. "Multiple-entry visa to travelling theory. Retranslations of literary and cultural theories". Target, vol. 15, no. 1, 2003, pp. 1-36.

Waquet, Nicolas. "Honorer son hôte. Une expérience de la retraduction". Retraductions. De la renaissance au XXIe siècle, edited by Christine Lombez, Université de Nantes, 2011, pp. 279-283.

Zabaloy, Marcelo. "Nota editorial". Ulises, by James Joyce, translated by Marcelo Zabaloy, El Cuenco de Plata, 2015, pp. 7-9.

Recebido em: 29/08/2018 Aceito em: 13/11/2018 Publicado em janeiro de 2019

Vitor Alevato do Amaral. E-mail: vitoramaral@id.uff.br ORCID: https://orcid.org/0000-0001-7838-5965 